Corresponding Author: Muhammad Thabran Talib; email: thabrantalib7@gmail.com

Published: 7 February 2022

Publishing services provided by Knowledge E

(c) Muhammad Thabran Talib and Syamsuddin. This article is distributed under the terms of the Creative Commons

Attribution License, which permits unrestricted use and redistribution provided that the original author and source are credited.

Selection and Peer-review under the responsibility of the IVCN Conference Committee.

\section{Completeness and Legal Implications of Patient Medical Records at Hajj Regional General Hospital of Makassar \\ Muhammad Thabran Talib* and Syamsuddin}

High School of Health Scince Panakkukang Makassar, South Sulawesi, Indonesia

\section{ORCID}

Muhammad Thabran Talib: https://orcid.org/0000-0002-7297-6251
Abstract. Information on a patient's health development can be obtained if the data contained in the medical record are filled out completely, accurately and consistently. This study aimed to analyze the completeness of medical records and the legal aspect of the use of medical records in health services. This research was carried out at Hajj General Hospital of Makassar. The study was conducted retrospectively with a qualitative approach through in-depth interviews, observation of medical record files and document review, as well as with a quantitative approach, from October to December 2020. 258 medical record files were reviewed, and informants included five implementing medical personnel and 10 implementing nurses, who were interviewed to examine opinions about the completeness and legality of ownership of medical record files. The results showed that there were still incomplete medical record files, and most medical record items were not filled out completely and consistently, which has legal implications in terms of the file owner and the contents of the medical record. For this reason, open communication is sought between all health workers.

Keywords: completeness, legality, medical record

\section{Introdution}

When examined regarding the meaning of medical records as information both written and recorded regarding the identity of anamnese, physical determination, laboratory, diagnosis, treatment and medical actions given to patients. Here the notion of medical records has a broader meaning than ordinary records, but has the meaning as a system of administering medical records in which all information about the patient's condition has been reflected which will be used as the basis for determining further action in the service and treatment provided, medical records are more meaningful as medical documents, because medical records have a broader meaning than just ordinary records. [1]. The basis for organizing medical records is emphasized in the Decree of the Minister of Health Republic Indonesia 269/2008, concerning Medical Records which are the legal basis for all medical personnel, nurses and administrative personnel involved in health services. The implementation technique refers to the 
Ministry of Health regarding the revision of the Guidelines for Management of Medical Records in Hospitals, which among other things states that medical record records can be used by hospitals to support orderly administration. In carrying out activities, medical record officers refer to the Medical Record Service Standards, which consist of 7 standards, namely (1) Philosophy and Objectives, (2) Administration and Management, (3) Staff and Leaders, (4) Facilities and Equipment, (5) Policies and Procedures, (6) Staff Development and Educational Programs, (7) Evaluation and Quality Control [12]. Studies of various sources of incompleteness and errors in filling out medical records are influenced by several factors. The sources in the hospital inpatient room can be described using the Places, Procedures, Policies, People and Systems-method Kaoru Ishikawa . Problem identification analysis can be traced in the form of Cause and Effect operationalized in the Medical Record Room at Hajj General Hospital of Makassar: 1) People, low awareness of officers, for example, files without medical record numbers, also with inadequate quality and quantity of human resources where education is not in accordance with their work and coordination between RM officers and other departments is still low. 2) Procedures, socialization of the use of medical record files as an illustration of the low quality of service, depositing files from the inpatient room which is often late to the medical record room and incompleteness and accuracy in filling out medical record files. 3) Places, medical record rooms and programs are not strategic, namely on the 2 nd floor, which is located far from the outpatient reception room and the medical record files stored in the room are rather narrow in retrieval and storage of medical record files. 4) Policies, the implementation of government policies through government regulations and procedures made by the Director General of Medical and Medical Services. Completely not implemented properly. This regulation was not implemented due to the lack of sanctions and included a policy of providing intensive incentives to staff who were still lacking. 5) Systems, computerization in the processing of hospital information systems has decreased because the data is not well organized and the other part is the daily census of inpatients which is not implemented optimally [3]. It was identified at Hajj Regional General Hospital of Makassar that in 2019 the number of incomplete medical record files and returned to the inpatient room for completion had increased from the previous year, as many as 105 medical records from various treatment rooms. this could indicate that the implementation of the completeness of medical record files in the inpatient room has not been running. as stipulated in the applicable policies and procedures. This is also stated in a study at RSIA Kendan Sari Merr Surabaya that there were as many as 80 incomplete medical records. As a result, the quality of medical record files is low so that in turn it will have 
TABLE 1: Completed summary of entry and exit at Hajj Regional General Hospital of Makassar, December $2020(n=258)$

\begin{tabular}{l|l|l|}
\hline Fill in the medical record file & Complete (\%) & Incomplete (\%) \\
\hline Medical Record Number & $193(74,8)$ & $65(25,2)$ \\
\hline Name of the person in charge & $177(68,6)$ & $81(31,4)$ \\
\hline Exit State & $146(56,6)$ & $112(43,4)$ \\
\hline How to get out & $183(70,9)$ & $75(29,1)$ \\
\hline Login Diagnostic & $153(59,3)$ & $105(40,7)$ \\
\hline Disease Code ICD-X & $222(86,1)$ & $36(13,9)$ \\
\hline Doctor's Signature & $208(80,6)$ & $50(19,4)$
\end{tabular}

an impact on the management and presentation of medical record data to be illegal in the legal aspect and the accountability of hospital reports and hospital information systems originating from medical records can be doubted [8].

\section{Methods and Equipment}

The study used the Analytical survey method, from correlation analysis which was carried out retrospectively with quantitative and qualitative approaches. Quantitatively by counting the number of medical record files as facts to analyze the completeness and legality of medical record files and qualitatively by in-depth interviews, observation and document review to find factors supporting and inhibiting medical record activities. Quantitative studies used as data sources are 258 medical record files, qualitative studies on the legality of medical record files by knowing opinions or interviewing 10 medical personnel and 20 nursing staff, to find out the ownership of the medical record file. To ensure the level of truth and validity of the data, validation was carried out by triagulation on the medical recorder, doctors and nurses. Data analysis with data collection, data condensation and data verification to record cause and effect that can be used as research conclusions. Quantitative presentation of data in the form of tables and Pareto graphs is related to the causes or problems from the most significant to the least significant and frequency tables. Presentation of data in qualitative form, namely the data obtained from informants will be presented in the form of in-depth interview narration.

\section{Result}

Filling in the Completeness of Medical Records 
TABLE 2: Completeness of resume sheets at Hajj Regional General Hospital of Makassar, December 2020 $(n=258)$

\begin{tabular}{l|l|l} 
Fill in the medical record file & $\begin{array}{l}\text { Complete } \\
(\%)\end{array}$ & Incomplete (\%) \\
\hline $\begin{array}{l}\text { Medical Record Number } \\
\begin{array}{l}\text { Chief complaint, current } \\
\text { illness }\end{array}\end{array}$ & $212(84,3)$ & $92(35,7)$ \\
\hline $\begin{array}{l}\text { Patient's condition out } \\
\text { Activity Date }\end{array}$ & $198(76,7)$ & $60(23,3)$ \\
\hline Doctor's Name & $116(45,0)$ & $142(55,0)$ \\
\hline
\end{tabular}

TABLE 3: Completeness Doctor's notes at Hajj Regional General Hospital of Makassar, December 2020 $(n=258)$

\begin{tabular}{l|l|l|}
\hline Fill in the medical record file & Complete (\%) & Incomplete (\%) \\
\hline Medical Record Number & $175(67.8)$ & $83(32.2)$ \\
\hline Activity hours & $138(53.5)$ & $120(46.5)$ \\
\hline Doctor's Name & $128(49.6)$ & $130(50.4)$
\end{tabular}

Fill in the incomplete discharge record, the largest percentage is 112 Incomplete (43.4\%) which does not include or is void in the patient's discharge state. incoming diagnoses were 105 Incomplete (40.7\%) and the name of the person in charge of patients receiving treatment was 81 Incomplete (31.4\%). Meanwhile, in the patient's resume sheet, which is made in a table that shows the following results:

According to the Indonesian Ministry of Health, stated that the purpose of this resume was (1) to ensure continuity of high-quality medical services as well as material used for receiving doctors when the patient was re-treated in the hospital. (2) As an assessment material for hospital staff. (3) To fulfill requests from official bodies or individuals regarding the care of a patient, for example from an insurance company (with the approval of the leadership). (4) To provide a copy to the expert system that requires records of the patients they have treated [12]. This resume should be able to explain important information about the disease, examinations performed and treatment. the following table:

Not including the doctor's name is a violation of the provisions on the fulfillment of the legal aspects of the medical record file. In Law, 29/2004, concerning Medical Practice, article 46 explains that medical practice is required to make medical records, must be completed immediately after the patient has finished receiving health services and each medical record must be affixed with the name, time and signature of the officer providing the service or action. In the nurse's notes, it was found that the names of many nurses were not filled with the following description: 
TABLE 4: Completeness of Nurse's records at Hajj Regional General Hospital of Makassar, December 2020 $(n=258)$

\begin{tabular}{l|l|l|}
\hline Fill in the medical record file & Complete (\%) & Incomplete (\%) \\
\hline Medical Record Number & $166(64,3)$ & $92(35,7)$ \\
\hline Progress Note & $178(69,0)$ & $80(31,0)$ \\
\hline Nurse Name & $73(28,3)$ & $185(71,7)$ \\
\hline Nurse Signature & $88(34,1)$ & $170(65,9)$
\end{tabular}

TABLE 5: Opinions of doctors and owners of medical record files at Hajj Regional General Hospital of Makassar, December 2020 ( $n=10)$

\begin{tabular}{l|l} 
Medical Record Owner & Score (\%) \\
\hline Doctor & $2(20,0)$ \\
\hline Doctors and Hospital & $1(10,0)$ \\
\hline Hospital & $7(70,0)$ \\
\hline Hospital and patient & $0(0,0)$
\end{tabular}

Notes that are filled in and not filled in by nurses after carrying out nursing actions will be an evaluation of nursing standards where in this condition nursing professionals who are more of a team work still do not write down names and signatures, so that this greatly interferes with the process of patient service information systems. in all care units in the hospital. Filling the report into consideration for nursing professional development as an analysis of legality and nursing education [5]. States that professionals who provide services for patients, have the right to make the contents of medical records, must document the services they provide. Identity can be a signature, recognized abbreviation or disease code. As an illustration of the analysis of the kelaglitas medical record files are as follows:

Doctor's opinion shows that the owner is a service institution or hospital with 7 doctors (70.0\%). Also to nurses as follows:

There were 8 nurses (80.0\%) who stated that the owner was a service institution or hospital. Each of the 4 nurses (40.0\%) thought it was a file belonging to the doctor,

TABLE 6: Opinions of nurses and owners of medical record files at Hajj Regional General Hospital of Makassar, December $2020(n=20)$

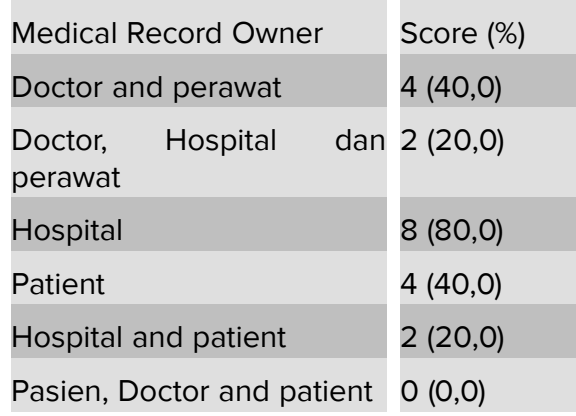


TABLE 7: Opinions of doctors and owners of the contents medical record files at Hajj Regional General Hospital of Makassar, December $2020(n=10)$

\begin{tabular}{l|l}
$\begin{array}{l}\text { Owner of the contents medical } \\
\text { record }\end{array}$ & $2(20,0)$ \\
\hline Doctor & $0(0,0)$ \\
\hline Doctor with nurse & $6(60,0)$ \\
\hline Patient & $3(30,0)$ \\
Hospital & $0(0,0)$ \\
\hline Hospital and patient &
\end{tabular}

TABLE 8: Opinions of nurses and owners of the contents medical record files at Hajj Regional General Hospital of Makassar, December $2020(n=20)$

\begin{tabular}{l|l}
$\begin{array}{l}\text { Owner of the contents medical } \\
\text { record }\end{array}$ & $4(40,0)$ \\
\hline $\begin{array}{l}\text { Doctor, nurse } \\
\text { Doctor with patient }\end{array}$ & $4(40,0)$ \\
\hline Patient & $7(70,0)$ \\
Hospital & $3(30,0)$ \\
\hline Hospital with patient & $2(20,0)$ \\
\hline Hospital, Doctor, nurse & $0(0,0)$
\end{tabular}

nurse and patient. Furthermore, from the doctor's opinion on the owner of the contents of the medical record file, it is described:

The opinion of doctors regarding the owner of the contents of the medical record file in the treatment room was 6 doctors $(60.0 \%)$ stating that the owner of the contents was the patient, while 3 nurses (30.0\%) thought that the contents of the medical record belonged to the hospital. Also the opinion of the nurse on the owner of the contents of the medical record file is:

There were 7 nurses (70.0\%) who stated that the owner of the contents was the patient. Each of the 4 nurses (40.0\%) thought it was the contents of the file belonging to the doctor, nurse and doctor with the patient. In order to reveal the above in more depth, the researcher initiated interviews with key informants who provided the following information:

"Medical record service activities are not understood by all staff in this hospital, therefore we always send these personnel every time there is training. But actually it's not only medical record personnel who have to know about it, right..... The benefits of medical records are huge in improving hospital management." (Informant 1)

To the informant with the question "how is the monitoring and implementation of medical record activities by doctors and nurses", then the answers are given as follows: 
"Monitoring in charge of medical records is still lacking. In filling out medical record files, our doctors and nurses are also still low in their willingness to complete files both when the patient is still being treated or when the patient has left, so our medical record personnel must be able to analyze the patient's medical record file and if there are still less, we immediately returned to the treatment room to be re-equipped." (informant 3)

The question "why the patient's medical record file is not filled out completely after the doctor provides services". Researchers get the following answers:

"I was busy with a lot of work, so....finally....I didn't have time to fill it out and collect patient data" (informant 4)

The researcher conveyed the same question to medical personnel and received different information, namely:

"We know that filling out the completeness of the status is important, including signing and writing my clear name as a doctor, but that's how it is" (informant 5)

The question given to the nurse: "Why are there so many blanks in the medical record file and not completed by the nurse". And then the answer by the nurse as follows:

"It's become our daily habit, so...for us it's not a big problem I think....." (informant 6) The other information provided by the informant is as follows:

"In several hospitals in the Region and Makassar the case is something that is legal and there have never been any problems that arise" (informant 7)

\section{Discussion}

Medical records contain information on every service provided by health facilities to patients. Medical records must be written in a timely manner and contain sufficient information to identify the patient, support the diagnosis, the reason for the patient's admission, prescribe treatment and produce accurate documentation. Managing the contents of medical records by means of documentation analysis is an important function of the medical record section of health care facilities [4]. By reviewing all medical records during or after services completely and accurately, health practitioners have made a very meaningful contribution to the facility. The analysis is carried out specifically for each health service depending on the regulations and needs of medical staff, administration, licensing requirements, accreditation and other certificate requirements. The purpose of this resume is (1) to ensure continuity medical services as well as material used by doctors who receive it when the patient is re-treated in the hospital. (2) As an assessment material for hospital staff. (3) To fulfill requests from official bodies or 
individuals regarding the care of a patient, for example from an insurance company (with the approval of the leadership). (4) To provide a copy to the expert system that requires records of the patients they have treated. This resume must be able to explain important information about the disease, examinations performed and treatment [5]. This explanation is supported by the results of research which states that more than $50 \%$ of nurses stated that the medical record as a document belongs to a health service facility or hospital and also that nurses know that the contents of the medical record belong to the patient. Legal aspects of medical records with the description that: (a) The main responsibility for the completeness of medical record files lies with doctors and nurses who treat patients, on the basis that medical records are used for health maintenance and treatment. (b) To complete information on medical records regarding the patient's medical history, among others, resume sheets can be delegated, but must be reviewed, corrected and signed by the treating doctor. (c) The completeness of this medical record is very important in the process of establishing a patient's diagnosis [6]. The Ministry of Health of the Republic of Indonesia, provides rules regarding the completeness of the medical record file that must be completed within $1 \times 24$ hours after the patient is treated and before surgery it must be written in the medical record sheet. After $1 \times 24$ hours, if there is an incomplete medical record file, the medical record officer will inform the authorized officer in the patient care room to conduct a medical audit. In order to fulfill the legality of medical record files, the general provisions in the regulation also explain: (a) Medical records are files containing records and documents regarding patient identity, examination, treatment, action, and other services to patients at health care facilities. (b) Health service facilities are places used to carry out health efforts, both for outpatient and inpatient treatment, which are managed by the government and the private sector [11].

Legality of Medical Records, Decree of the Minister of Health Republic Indonesia. 269/2008, concerning Medical Records in Chapter III concerning Owners and Utilization, Article 10 that (1) Medical record files belong to health service facilities. (2) The contents of the patient's medical record must be kept confidential. Article 11 states that medical records are files that must be kept confidential. The hospital director is responsible for (1) Loss, damage or falsification of medical records. (2) Use by unauthorized entities or persons. To protect the confidentiality, provisions are made (1) Only medical record officers are allowed to enter the medical record file storage room. (2) It is forbidden to quote part or all of the contents of medical records for entities or individuals, except when it has been determined by the prevailing laws and regulations [10]

\section{Analysis of Completeness and Legality of Medical Records}




\subsection{Supporting Factors}

1) Facilities and infrastructure factors for medical record activities are sufficient and sufficient to get management attention with the availability of needs ranging from writing instruments, outpatient reception rooms, inpatient care, processing, data analysis to computer system networks as information media.

2) Human Resources Factors with medical personnel, nursing staff and administrative staff are quite a lot and there is time to complete and complete medical records under the supervision of the medical committee. The existence of sanctions for doctors who do not complete the task of completing medical records is also an incentive for doctors who are responsible for completing tasks on time. Officers in the medical record unit who have an educational background in medical records and adequate health information (minimum D3 Medical Recorder education) understand the implementation of activities, grouping, analysis of activities, philosophy and uses of medical records

3) The cost factor is the availability of costs and the use of budgets for adequate medical record management activities, as evidenced by the availability of medical record forms or files that comply with the minimum standards of the Ministry of Health regulations, computers that meet standards, stationery and other facilities and infrastructure

4) The procedural factor is the availability of standard medical record management procedures that refer to the Decree of the Minister of Health regarding the revision of guidelines for managing medical records in hospitals and the manual for managing medical records for hospitals in Indonesia [4].

\subsection{Obstacle Factor.}

The duties and responsibilities of doctors and nursing staff show that the implementation of medical record activities is not fully in accordance with medical record management standards, which is caused by many things that are not good, including awareness to carry out the task caused by factors originating from from each doctor and nurse, namely because they feel it is not so important to do or because of the laziness factor of the health workers themselves. The results of in-depth interviews showed that doctors who worked at Hajj Regional General Hospital of Makassar had a lot of free time to complete, including signing medical record files, but even so, doctors still forgot to complete and affix their signatures. Furthermore, although the doctor in question realized the importance of a signature and a clear name, he did not really care. Whether it will be bad in the future, seems not to know or can not be thought of. 
In achieving the legality of the medical record file that every recording into the medical record must be signed by a doctor or other health worker who provides services or actions in accordance with their authority, their full name is written and the date is given [2]. The responsibility for the medical record lies with the doctor who treats the patient, although the filling can be delegated to a co-assistant, expert assistant or other doctor, but the final responsibility for its contents lies with the treating doctor. Another thing found in the completeness and legality of this medical record file is that it is explained that it is not entirely the doctor's fault, because legally he is not completely filled in, but also filled in by the patient reception section at the Inpatient Reception Center. But it can also remind the officer to fill it out. The causative factor is that nurses in the treatment room feel that it has become a habit that can be considered legitimate and not a big problem, this is also due to a lack of knowledge about medical record service standards. in the 5th standard on policies and procedures it is explained that doctors, nurses and non-professional medical professionals are responsible for the correctness and accuracy of filling out medical records and this is regulated in the articles of association, hospital work regulations and guidelines with the understanding that the medical history and examination results must be complete within 24 hours after the patient is admitted and before the operation and all medical record reports must be complete no later than 14 days after the patient goes home unless the test and autopsy results have not there is [13]. As for what needs to be paid attention to from the nurse's explanation that we have recorded all the activities we have done, some hospitals like that are something that is legal and there have never been any problems that arise. In analyzing file analysis, both quantitatively, namely reviewing patient identity checks, reviewing all important reports, reviewing patient authentication and reviewing the creation of good medical record implementation as well as quantitative analysis, namely review of complete and consistent diagnostic statements, review of consistency of entry, review of description and justification of treatment directions, review of recording informed consent, review of practice documentation and review of events that can get compensation [14]. Management of the contents of medical records through analysis of medical records is an important function for health information in all health care facilities, by reviewing all medical records during or after service for completeness and accuracy, health information practitioners make a real contribution to hospitals. Medical records contain relevant information about a patient being provided with care, must be written in a timely manner and contain information to identify the patient, support the diagnosis, justify treatment and accurately record the results. The form of analysis carried out specifically depends on the policy and is regulated by the health 
service facility. In general, the results of this study can conclude that the occurrence of incomplete medical record files is caused, among others, by low motivation to fill out medical record files and lack of sensitivity in filling out medical record files. It is said that attitude is a determining factor for behavior change. Attitude describes a person's likes or dislikes towards an object, while according to Rogers, attitude is a person's opinion or view about an object that precedes his actions. While a positive attitude will produce positive work, in this case it will produce good quality medical records. Some officers considered that the notes in the medical record were less important so they were forgotten [7]. The completeness of the contents or items in the medical record file is important because it is authentic evidence that is in accordance with the philosophy of medical records containing Medical, Administrative, Legal, Financial, Research, Education, Documentation (MALFRED) values. Constitution $36 / 2007$, concerning health articles $53,54,55$ it is stated that medical record files are authentic evidence and legal responsibility for health services provided by health workers to recipients of health services or patients.

\section{Conclusion}

From the results of research conducted on 10 forms of medical record files for Inpatients at Haji Makassar Hospital, the most medical record number items were not filled in as patient medical data and information. Other medical data also does not include the final state of the patient when they are discharged, including the writing of inpatient diagnoses, which are mostly not filled in as much as $40.7 \%$, so the legality standards of medical records need to be known both in terms of the owner of the file and the contents of the medical record. For this reason, open communication is sought between all health workers and forming a medical record committee in monitoring and evaluating the results of activities for filling out the completeness of the medical record file. Legality refers to the Decree of the Minister of Health of the Republic Indonesia, 269/2008, concerning Medical Records which the rules explain that medical record files belonging to health service facilities and the contents of medical records belonging to patients are found: 1) There are 10 respondents in the surgical treatment room, inside, children and midwifery, there are 7 doctors (70\%) who state that the owner of the medical record file is a health service facility or hospital. 2) There are also 20 respondents to nurses in the treatment room giving the opinion that the owner of the medical record file is a health service facility or hospital as many as 8 nurses (80\%). 3) The opinion regarding the contents of the medical record file according to the doctor belongs to the patient, 
this was stated by 6 doctors (60\%) and others said that it belonged to the hospital as many as 3 doctors (30\%). 4) The opinion of nurses who said that the contents of the medical record file belonged to the patient as many as 7 nurses $(70 \%)$, others said that it belonged to doctors, nurses and doctors with each patient as many as 4 nurses (40\%). Suggestions to improve medical audits of all medical record files of patients who have returned home which of course must involve committees in hospitals such as medical committees, nursing committees and medical records committees. Give feedback on the number of incomplete medical record files to each unit of the treatment room by compiling things that are incomplete and explaining the percentage of incompleteness made in the room. A legal protection unit is formed that functions to provide legal protection for patients, doctors, nurses, other health workers and the hospital as a whole.

\section{Acknowledgement}

Thanks are addressed to Health of Scince Panakkukang Makassar and all leaders who have provided support and enthusiasm in completing this research. Thanks are also conveyed to the Haji Makassar Hospital, especially the medical record unit which has provided the opportunity to conduct research and to all parties involved both morally and materially so that research can be useful and become useful reading for increasing knowledge, especially in the field of Medical Records and Health Information.

\section{References}

[1] Faida EW. Evaluasi kelengkapan pengisian dokumen rm instalasi ri dengan pendekatan analisis kualitatif dan kuantitatif di RSIA kendan sari merr surabaya. Jurnal Manajemen Informasi Kesehatan Indonesia. 2017;5(1):46-52.

[2] Sakidjan I. Analisis kelengkapan catatan rekam medis kasus tetralogy of fallot pada implementasi INA-CBGs di rumah sakit pusat jantung harapan kita. Jurnal Administrasi Rumah Sakit Indonesia. 2013:26-31.

[3] Suprijanto R. Aspek strategi manajemen rumah sakit-antara misi sosial dan tekanan pasar. Yogyakarta: Penerbit Andi Office; 2005.

[4] Hatta GR. Pedoman manajemen informasi kesehatan di sarana pelayanan kesehatan: Revisi buku petunjuk teknis penyelenggaraan rekam medis/medical record rumah sakit dan pedoman pengelolaan rekam medis rumah sakit di Indonesia. $2^{\text {nd }}$ ed. Jakarta: Penerbit Unversitas Indonesia, UI Press; 2012. 
[5] Huffman EK. Medical record management. 10 ${ }^{\text {th }}$ ed. Berwyn: Physicians Record; 1994.

[6] Naiem, M. F., Indar, I., \& Indar, I. Faktor yang berhubungan dengan kelengkapan rekam medis di rsud h. padjonga dg. ngalle takalar. Jurnal AKK UNHAS. 2013;2(2):1018.

[7] Lihawa C. Pengaruh motivasi kerja terhadap kinerja dokter dalam kelengkapan pengisian rm dengan dimoderasi karakter individu (Studi di RD islam unisma malang). Aplikasi Manajemen. 2016;14(12):300-308.

[8] Budi SC. Manajemen unit kerja rekam medis. Yogyakarta: Penerbit Quantum Sinergis Media Kota; 2011.

[9] Kepmenkes RI. No. 129MENKES/SK/II/2008, Standart pelayanan minimal rekam medis rumah sakit di Indonesia (Bab XIV rekam medis). 1997.

[10] Kepmenkes RI. No. 269/MENKES/SK/II/2008, tentang rekam medis.

[11] Winarti, S. S. Analisis kelengkapan pengisian dan pengembalian rekam medis rawat inap rumah sakit. Jurnal Administrasi Kesehatan Indonesia UGM. 2013;1(4):345-351.

[12] Depkes Rl. Pedoman pengelolaan rekam medis rumah sakit di Indonesia. Dirjen yanmed. Jakarta: Depkes Rl; 1997.

[13] Alaydrus S. Perbandingan kelengkapan pengisian rekam medis antara rumah sakit di Indonesia. Jakarta: Universitas Indonesia Press; 2011.

[14] Solikhah, S., Pamungkas, T. W., \& Marwati, T. Analisis ketidaklengkapan pengisian berkas rekam medis di rumah sakit PKU muhammadiyah Yogyakarta. Kes Mas: Jurnal Fakultas Kesehatan Masyarakat Universitas Ahmad Daulan. 2010;4(1):1-75.

[15] Undang-undang RI. no. 29 tahun 2004 tentang praktik kedokteran.

[16] Undang-undang RI. no. 44 tahun 2009 tentang rumah sakit.

[17] Undang-undang RI. no. 29 tahun 2004 tentang tenaga kesehatan. 